鼻腔内血管平滑筋脂肪腫例

前田亜貴子 ・深澤啓二郎・八田 千広

櫻井 一成* ·阪上 雅史

\title{
A Case of Angiomyolipoma of the Nasal Cavity
}

\author{
Akiko Maeda, Keijiro Fukazawa, Chihiro Hatta, \\ Kazunari Sakurai and Masafumi Sakagami \\ (Hyogo Collage of Medicine)
}

\begin{abstract}
A rare case of intranasal angiomyolipoma is reported. A 48-year-old male presented with a slowly progressive right nasal obstruction and recurrent epistaxis of the right nasal cavity. An intranasal examination showed a soft and easily bleeding mass in the right anterior nares. CT scan findings showed an enhanced soft tissue mass arising from the anterior edge of the right inferior turbinate without bony destruction. The patient had no clinical signs of tuberous sclerosis. The tumor was removed through the vestibule using a transoral approach under general anesthesia. Histopathologically, the tumor was composed of mature fat cells, vascular spaces lacking elastic tissue, and bundles of mature smooth muscle cells. There has been no recurrence for two and half years.
\end{abstract}

Key words : angiomyolipoma, nasal cavity, transoral approach

はじめに

血管平滑筋脂肪腫は良性で一種の過誤腫と考光られ， 組織学的には壁の厚い血管を取り巻くように平滑筋成分 が不規則に増生し，その間を埋める分化した脂肪組織成 分が存在するのが特徵である11.一般には女性の腎蔵， 後腹膜に多く発生し2), まれに肝臓, 縦隔, 皮膚, 生殖 器3) とみられ，鼻腔内はきわめてまれといわれて抢り， われわれが検索した範囲では, 欧文文献 3 例4 ${ }^{4) 6)}$, 本邦 では 1 例》が報告されているにすぎない，今回われわれ は鼻腔内に発生した血管平滑筋脂肪腫の 1 例を経験した ので報告する。

\section{症例}

症例 : 48歳, 男性.

現病歷 : 平成 8 年 4 月頃より右鼻閉がみられていた.
右鼻腔内腫瘤に気付き, 右鼻出血を繰り返していたが放 置していた. 平成 9 年 4 月，右鼻出血が頻回となったた め, 近医耳鼻咽喉科受診し右鼻腔内腫瘍を指摘され，そ の翌日精査加療目的にて当科紹介受診となった．経過中， 疼痛は認めなかった。

既往歷 : 高血圧, 糖尿病を指摘されていたが加療は受 けていなかった。

家族歷：特記すべきことなし.

現症 : 腫瘍は右鼻腔入口部より鼻外へ突出するほどの 大きさで，右鼻背は腫脹していた．表面平滑で充実性， 易出血性の腫瘍を認め，その基部は明らかではなかった が，鼻中隔とは離れていた(図 1). その他の耳，咽喉頭 領域には著変なく, 頸部リンパ節の腫脹も認められな かった．空腹時血糖 $265 \mathrm{mg} / \mathrm{dl}$ ，尿糖 $3+$ である以外は， 末梢血液, 生化学検査には異常を認めなかった。平成 9 


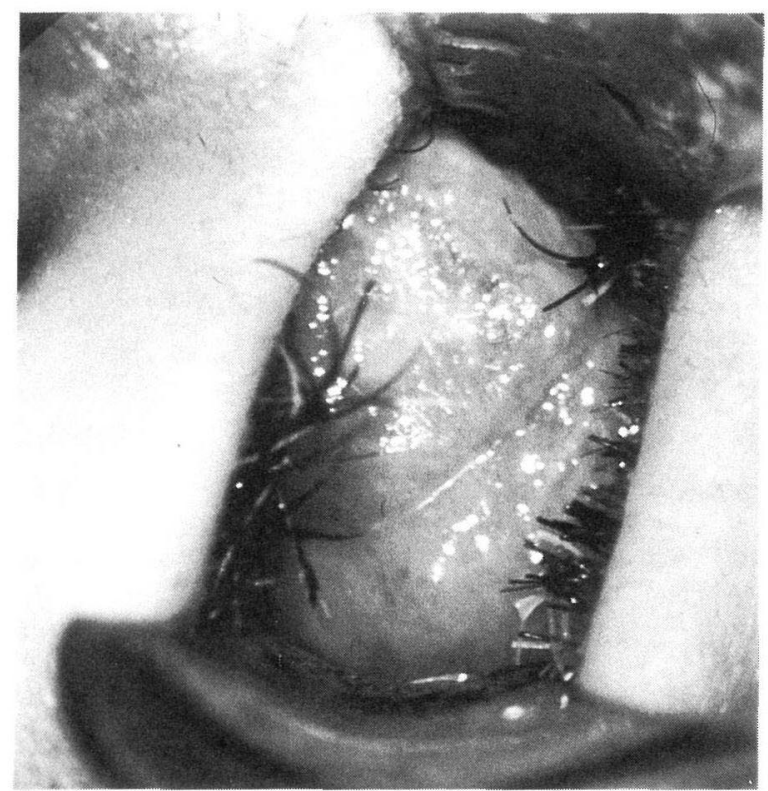

図 1 前鼻鏡所見

表面平滑で充実性, 易出血性の腫痬を認める.

年 4 月 8 日, 外来での生検の結果は鼻茸であった.

CT 所見: 腫瘍は造影 CT にて軽度造影され, 右鼻腔
内を充満し分葉を形成していた，副鼻腔は左上顎洞内に 炎症を思わせる陰影を認めるのみであった。腫瘍は右下 鼻甲介前方より発し鼻前庭を占拠して法り，鼻中隔とは 離れていた。骨破壞像は認めなかった(図 2 )。

MRI 所見：腫瘍は $\mathrm{T} 1$ 強調像で低信号域， T2 強調像 で高信号域，Gd 造影では均一に造影され，高信号域を 示していた(図3).

以上より鼻腔内腫瘍と診断し，平成 9 年 4 月 30 日, 全 身麻酔下に右鼻腔内腫瘍摘出術を施行した。腫瘍の発生 部位が確実に同定できなかったこと，悪性腫瘍の可能性 を否定できなかったことにより，Denker 法の手術圶想 定して手術を開始した。

手術所見 : 右犬歯窩歯肉部に切開を入れ，粘膜を剥離 挙上し梨状口縁に切開を加光，鼻腔内圭明視下に拈いた ところ，腫瘍は有茎性であり，その基部は下鼻甲介下鼻 道側から下鼻道側壁に認めた。 そのため, その基部周囲 約 $1 \mathrm{~cm}$ の粘膜を安全域としてとり，腫瘍と一塊に完全 摘出した。術中迅速病理診断は血管平滑筋脂肪腫であっ た。

摘出物：腫瘍は弾性硬で分葉を形成し，大きさは 28 ×25×20 mmであった(図 4).

病理所見：多列線毛円柱上皮あるいは重層扁平上皮に
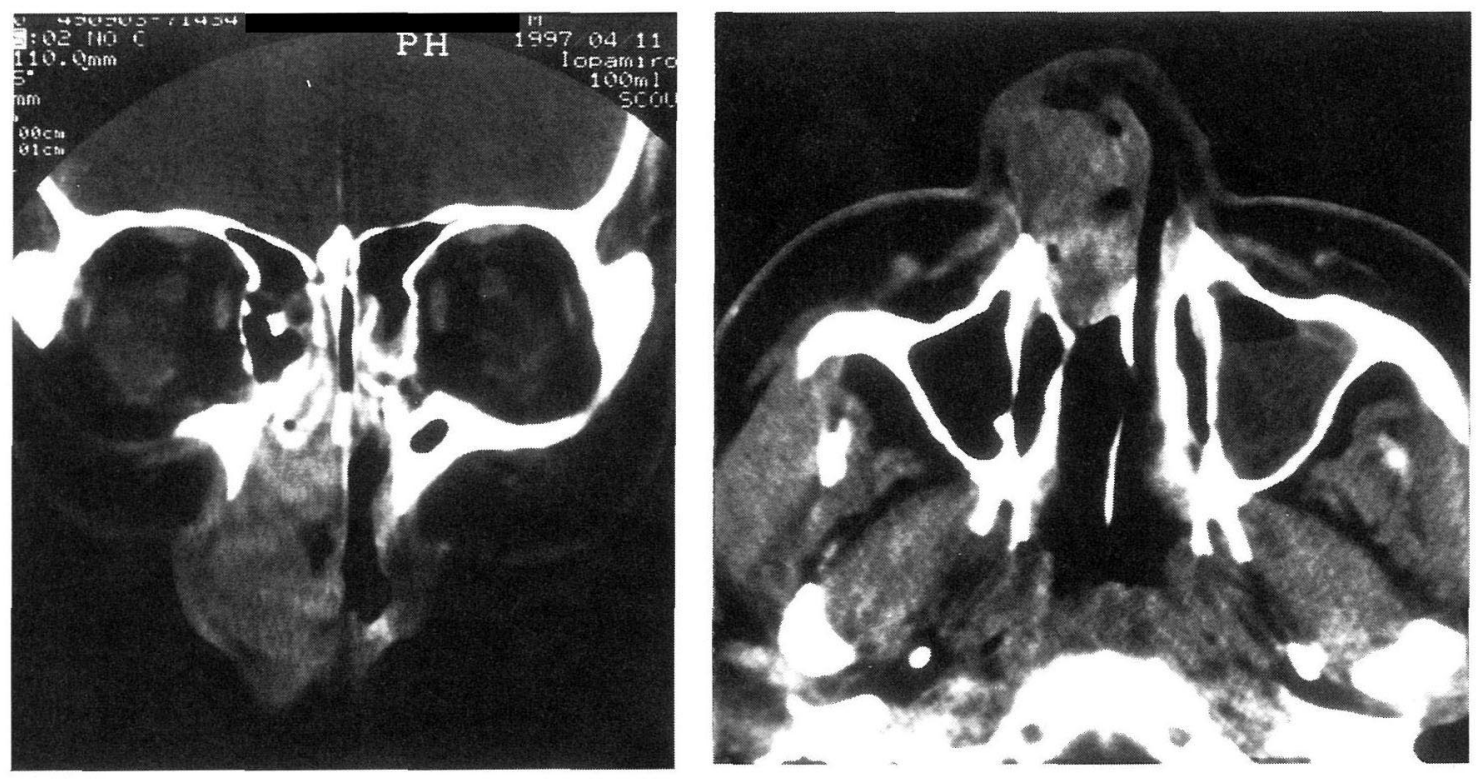

図2 造影 $\mathrm{CT}$ 像

左 : 前額断 右鼻腔を充満し分葉形成する腫瘍を認める.

右：水平断右下鼻甲介前方より鼻前庭支占拠寸る腫瘍を認める. 

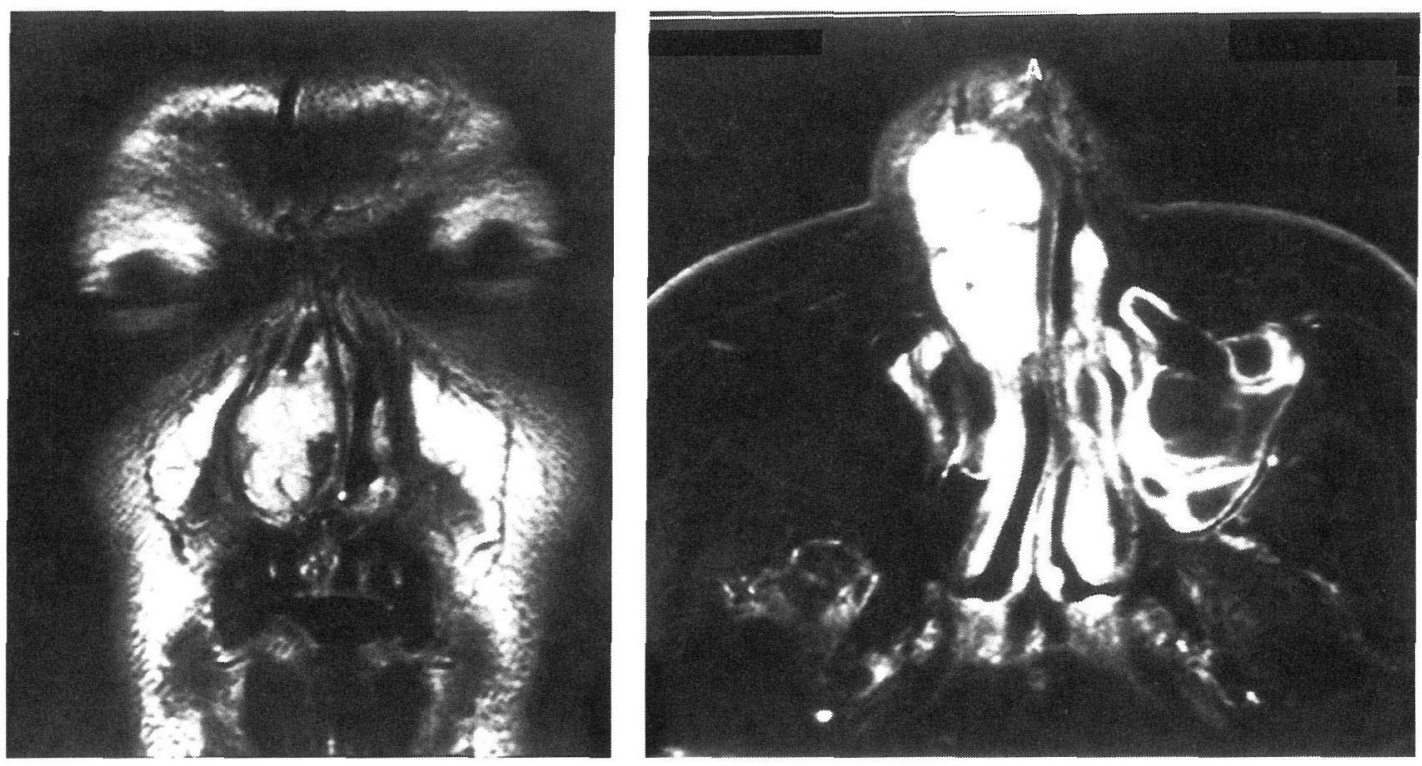

図 $3 \mathrm{Gd}$ 造影 MRI 像 (左 : 前額断 右: 水平断)

前額断，水平断ともに Gd に均一に造影され，高信号域を示し分葉形成する腫瘍を認める.

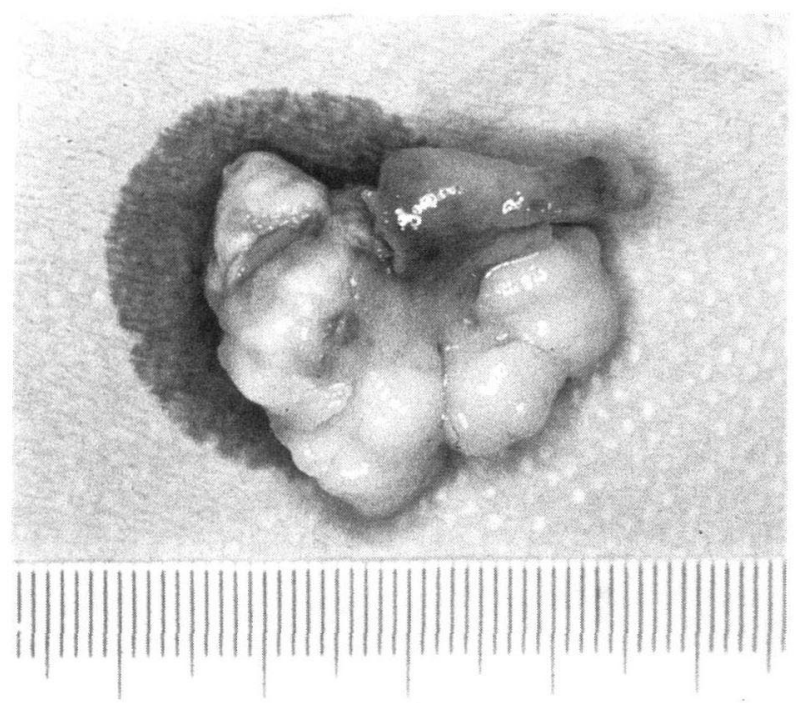

10

図 4 摘出標本

腫瘍は約 $28 \times 25 \times 20 \mathrm{~mm}$ の弾性硬で分葉を形成してい た.

覆われた腫瘍組織で, 内部には壁肥厚性の血管群の増生 を主体に, 平滑筋成分の増生叔よび成熟脂肪細胞群の混 在を認めた(図 5)。 。た，兔疫組織化学では増生血管の 内腔側には Factor-VIII (第 8 因子関連抗原), CD34 扎よ
びUEA-I が陽性であった。血管壁内特よび增生する 平滑筋成分では $\alpha$-smooth muscle actin は陽性であった が, HMB-45 (melanocytic cell-specific monoclonal antibody) は陰性であった。悪性所見は認めなかった(図 $6)$.

以上より腫瘍は血管平滑筋脂肪腫と診断された。術後 2 年 6 力月を経過しているが，再発，出血なく経過は良 好である。

\section{考察}

血管平滑筋脂肪腫 (angiomyolipoma) はまれな良性腫 瘍であり，1951年に Morgan ら 8 が腎病変を報告したの が最初である。一般に婜蔵に発生することが多く，結節 性硬化症の約 $30 \%$ に合併するといわれている113) 5)，腎 臓以外では肝藏や子宮にみられることがある3) 5)。頭頸 部領域で発生することはまれで, 硬口蓋9), 頓粘膜10)の 報告もあるが，鼻腔内の報告は 4 例にすぎない、4) 7).

病理組織学的には, 一般に脂肪組織, 平滑筋, 血管成 分および結合織間質よりなるが，その構成比率は症例に よって異なる。本症例では本来の鼻腔粘膜多列線毛円柱 上皮あるいは重層扁平上皮に覆われ，内部には壁肥厚性 の細静脈に類似した血管群の増生を主体に，不規則な走 行を示す平滑筋成分が認められた。これに混在して, 所 

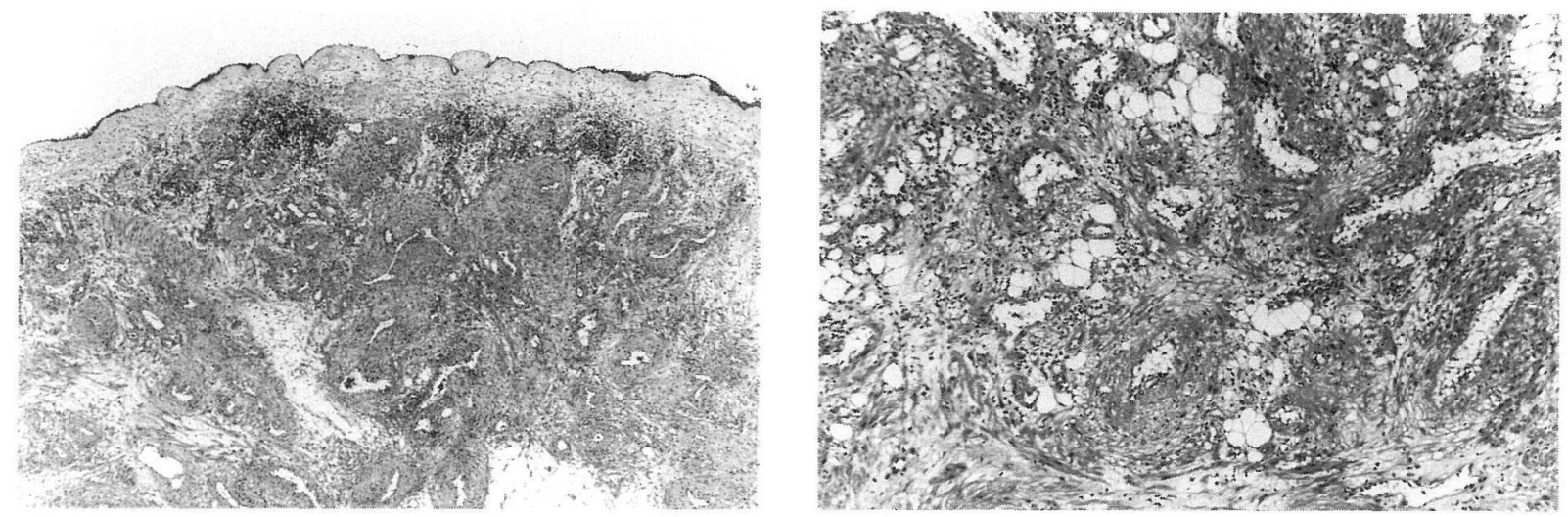

図 5 病理組織標本(HE 染色 40倍(左), 100倍(右))

壁の厚い血管を多数認め，その間に平滑筋成分と成熟した脂肪組織をみる.
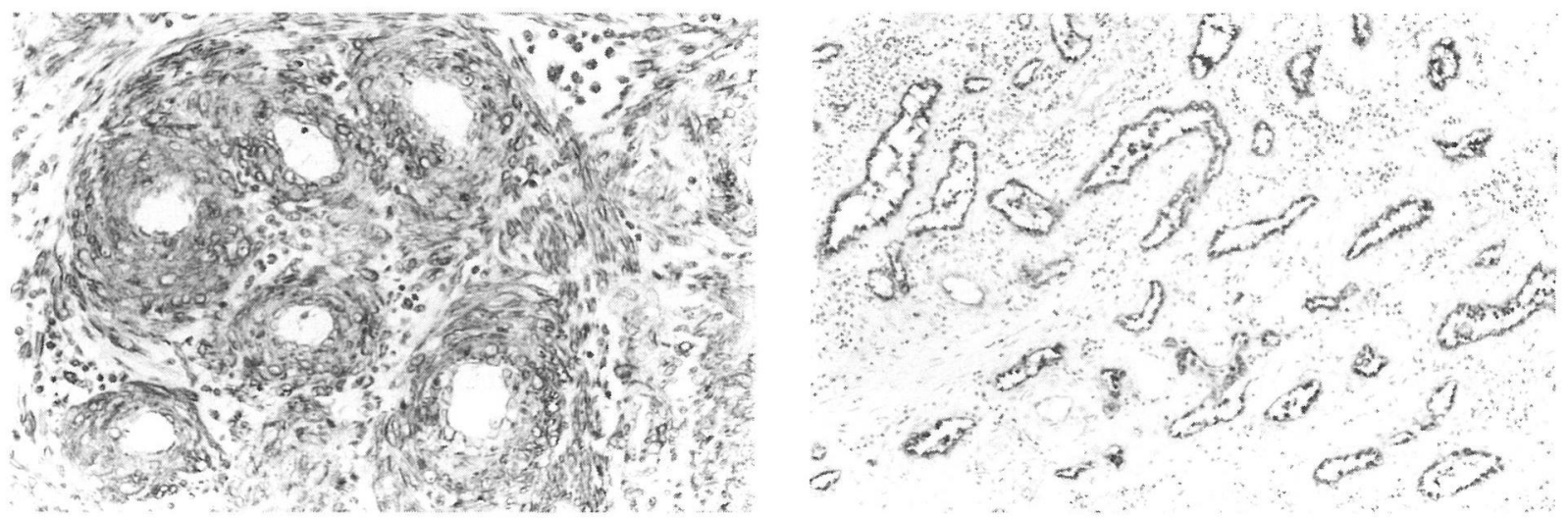

図 6 免疫組織標本 $(\alpha$-SMA 200倍, Factor-VIII 100倍)

左： $\alpha$-SMA 陽性所見 血管平滑筋を主体に陽性である。

右 : Factor-UII 陽性所見 血管内皮細胞に一致して陽性である.

所にやや大小不同性の成熟脂肪組織群の増生が示された. 屯た，栄養血管の一部之みられる細動脈性血管群も散見 された.免疫組織化学的には血管の内皮細胞に特異的な

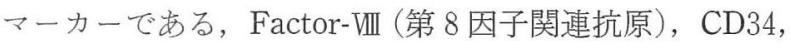
UEA-I (lectin) が増生血管の内腔側飞は陽性であった。 また，血管平滑筋細胞に特異的なマーカーである $\alpha$ smooth muscle actin も平滑等成分に打いて陽性であっ た. 腎発生例では多発性襄胞の併存䏡上び筋原性細胞に 扣沪るHMB-45 (melanocytic cell-specific monoclonal antibody) の陽性所見が示唆されることが多い11)。しか

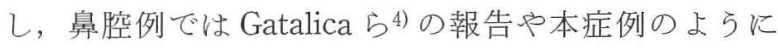
HMB-45 は陰性であり，過誤腫的な要素を含むるのの 通常腎でみられるものとは本質的に異なるものと推察さ
れる。

血管平滑筋脂肪腫の鼻腔内の発生部位は, 現在まで報 告されている 4 例中 3 例が鼻前庭部にみられていた4)577. 本症例子発生基部は下鼻甲介下鼻道側から下鼻道側壁に かけてあり, 鼻前庭を占拠していた。組織型と発生部位 との関係は不明であるが注目すべさ点と思わ机る。

診断については臨床症状やCT, MRI などの画像から は他の鼻腔内良性腫瘍とは区別できないため, 最終的に は病理組織学的な診断が必要である。治療は 4 例之も外 科的に摘出され，ぬた18２4力月の観察期間で再発は認

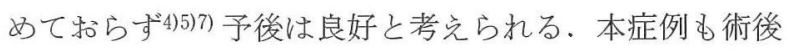
2 年 6 カ月を経過しているが再発は認めていない.

鼻, 副鼻腔は, 呼吸上皮抒よび粘液腺の他, 豊富な血 
管系, リンパ組織, 神経, 骨, 歯牙組織, 口腔側の小唾 液腺などさまざまな発生母地を含むため, 鼻, 副鼻腔に 発生する良性腫瘍の発生頻度は低いるのの種類は多彩で ある. 上皮性腫瘍には乳頭腫, 腺腫, 混合腫瘍がある. その他, 神経原性腫瘍, 結合組織性として線維腫と血管 腫, 骨性として骨腫, さらに鼻前庭囊胞も含まれる。そ のなかでも乳頭腫と血管腫をあわせて約 6 ～ 7 割を占め ることが報告されている12). 今回われわれの経験した血 管平滑筋脂肪腫は非上皮性腫瘍のその他に分類され，本 邦では 2 例目の報告となり，きわめてまれな腫瘍であっ た。

$$
\text { まとめ }
$$

鼻腔内に発生した血管平滑筋脂肪腫の 1 例を報告した. きわめてまれな腫瘍で最終的には病理組織学的な診断を 必要とした．完全に腫瘍摘出を行えば再発せず予後良好 な腫瘍と考兄られた。

\section{参考文献}

1) 藍澤宗一, 菊池昌弘, 原弘, 他 : 腎臓, 膀胀. 組織病 理アトラス. 182頁, 光文堂, 東京, 1995.

2 ) 丸山孝士 : 軟部組織の腫瘍. 新病理学各論(菊地浩吉, 吉 木 敬編). 667頁, 南山堂, 東京, 1992.

3 ) 真鍋俊明 : 問題のある血管筋脂肪腫. 病理と臨床 $8: 767$ $\sim 777,1990$.
4) Gatalica Z, Lowry LD and Petersen RO : Angiomyolipoma of the nasal cavity ; case report and review of the literature. Head Neck $16: 278 \sim 281,1994$.

5 ) Dawlatly EE, Anim JT, El-Hassan AY, et al : Angiomyolipoma of the nasal cavity. J Laryngol Otol 102 : 1156 1158, 1988.

6 ) Guezmes A, Mazorra F, Garcia-Mantilla F, et al : Nasal angiomyolipoma. Acta Otorrinolaringol Esp $41: 341 \sim$ $342,1990$.

7 ) 大月直樹, 石田春彦, 埴岡啓介, 他 : 鼻腔 Angiomyolipoma の一例. 日鼻誌 $32: 141,1993$.

8 ) Morgan GS, Straumfjord JV and Hall EJ : Angiomyolipoma of the kidney. J Urol $65: 525 \sim 527,1951$.

9 ) Gutmann J, Cifuentes C, Vicuna R, et al : Intraoral angiomyolipoma. Oral Surg $39:$ 945 948, 1975.

10）小宮義昭, 岩本昌平, 化瓶義郎, 他 : 煩部に発生した血管 筋脂肪腫の 1 例. 日口外誌 $29: 1761 \sim 1764,1983$.

11）櫻井一成, 山田章彦, 八十嶋化, 他: 鼻腔内に発生した血 管筋脂肪腫の 1 例. 病院病理 $16: 25,1998$.

12) 酒井俊一：鼻腔良性腫瘍. 耳鼻咽喉科治療大系(野村恭也 編). $66 \sim 67$ 頁, 講談社, 東京, 1986.

$$
\left(\begin{array}{l}
\text { 原稿受付 : 平成 } 12 \text { 年 } 2 \text { 月 } 8 \text { 日 } \\
\text { 原稿採択 : 平成 } 12 \text { 年 } 3 \text { 月 } 22 \text { 日 } \\
\text { 別刷請求先 : 前田亜貴子 } \\
\text { 干 } 663-8501 \text { 西宮市武庫川町 } 1-1 \\
\text { 兵庫医科大学耳鼻咽喉科学教室 }
\end{array}\right)
$$

